\title{
The Removability of Non-Citizen Parents and the Best Interests of Citizen Children: How to Balance Competing Imperatives in the Context of Removal Proceedings
}

\author{
By \\ Patrick Glen*
}

I.

INTRODUCTION

With comprehensive immigration reform effectively stalled in the United States (US) Congress and ripples of discontent still roiling domestic and international financial and economic markets, illegal immigrants again have become a convenient target for an emergent nativist sentiment in the United States and abroad. In Europe, this sentiment has taken on ugly overtones, complete with threatened and real violence against new arrivals, both legal and illegal. ${ }^{1}$ The rhetoric has not always been as heated in the United States, but the preceding three years have seen a sharp rise in state legislation both to curb illegal immigration and to make it easier to discern those who are present in the United States illegally. State laws from Arizona, ${ }^{2}$ Georgia,${ }^{3}$ and Alabama ${ }^{4}$ have taken

* Adjunct Professor, Georgetown University Law Center; Attorney, Office of Immigration Litigation, United States Department of Justice. The views and opinions reflected in this article do not represent those of the federal government or Department of Justice.

1. See, for example, Jennifer M. Pacella, Welcoming the Unwanted: Italy's Response to the Immigration Phenomenon and European Union Involvement, 25 GEO. IMMIGR. L.J. 341, 350-54 (2011); Damaso Reyes, Living in the Shadows: Navigating Austria's Evolving Asylum Policy, WORLD POL'Y J., Winter 2010/2011, at 87.

2. See S.B. 1070, 49th Leg., 2d Reg. Sess. (Ariz. 2011). The Ninth Circuit has enjoined enforcement of large sections of the Arizona law. See United States v. Arizona, 641 F.3d 339, 344 (9th Cir. 2011). Arizona since has filed a petition for certiorari, which, as of the date of this writing, has not been acted on by the Supreme Court. Ariz. Asks High Court to Rule on SB 1070, ARIZ. Republic, Aug. 11, 2011, at A1.

3. See H.B. 87, 151st Gen. Assemb., Reg. Sess. (Ga. 2011). In July 2011, a federal judge in Georgia issued a preliminary injunction against enforcement of the law. Eric Stirgus, Georgia Immigration Law No Mere Federal Follower, AtLantA J. Const., July 18, 2011, at B1.

4. See Laws Act 2011-535, H.B. 56, 2011 Leg., Reg. Sess. (Ala. 2011). Parts of the Alabama 
center stage in this drama, but these states are by no means alone. One specific effect of this general reaction against illegal immigrants is a renewed focus on the conferral of US citizenship through the jus soli principle, that is, birth in this country. ${ }^{5}$

On January 5, 2011, State Legislators for Legal Immigration, an organization composed of state lawmakers from across the United States, unveiled a model citizenship law that would define who is a citizen under both state law and the Federal Constitution, thereby taking aim at jus soli citizenship. ${ }^{6}$ The proposed model law represents an attempt to reverse a century-old constitutional interpretation of the citizenship clause of the Fourteenth Amendment, which provides that "All persons born or naturalized in the United States, and subject to the jurisdiction thereof, are citizens of the United States and of the State wherein they reside." 7 The Supreme Court last interpreted the scope of the citizenship clause in 1898, when it held, with very limited exceptions, that the Constitution establishes jus soli citizenship - the conferral of US citizenship on those born in this country. ${ }^{8}$

The model law attempts to limit the prevailing interpretation of the citizenship clause by defining the phrase "subject to the jurisdiction thereof":

[S]ubject to the jurisdiction of the United States has the meaning that it bears in Section 1 of the Fourteenth Amendment to the United States Constitution, namely that the person is a child of at least one parent who owes no allegiance to any foreign sovereignty, or a child without citizenship or nationality in any foreign country. For the purposes of this statute, a person who owes no allegiance to any foreign sovereignty is a United States citizen or national, or an immigrant accorded the privilege of residing permanently in the United States, or a person without citizenship or nationality in any foreign country. ${ }^{9}$

To the extent that the aforementioned model citizenship law is contrary to the Supreme Court's decision in Wong Kim Ark, and fails to offer any compelling justification for reversing that constitutional interpretation, its fate would seem clear. ${ }^{10}$

law have been enjoined by the Eleventh Circuit Court of Appeals, Stephen Ceasar, Appeals Court Puts a Hold on Parts of Tough Alabama Immigration Law; But Panel Upholds Provisions Targeting Contracts, Licenses, CHI. TRIB., Oct. 15, 2011, at 7, while a bill has been introduced in the Alabama Senate to repeal the act. See S.B. 41, 2012 Leg., Reg. Sess. (Ala. 2011).

5. United States v. Wong Kim Ark, 169 U.S. 649, 667 (1898).

6. See State Lawmakers Convened in D.C. to Deliver Historic, Nationwide Correction to the 14th Amendment Misapplication, State Legislators FOR Legal ImMigration (Jan. 5, 2011), http://www.statelegislatorsforlegalimmigration.com/NewsItem.aspx?NewsID=10195.

7. U.S. CONST. amend. XIV, $\S 1$.

8. See Wong Kim Ark, 169 U.S. 649; see generally Patrick J. Glen, Wong Kim Ark and Sentencia que Declara Constitucional la Ley General de Migración 285-04 in Comparative Perspective: Constitutional Interpretation, Jus Soli Principles, and Political Morality, 39 U. MIAMI INTER-AM. L. REV. 67, 73-80 (2007).

9. Bill $\S$ (b), State Legislators for Legal Immigration (Jan. 5, 2011), http://www.azcentral.com/ic/pdf/0105birthright-citizenship-legislation.pdf.

10. See Glen, supra note 9, at 103-07 (discussing whether there are any grounds that would 
This proposal, and others like it, however, has gained momentum by taking aim at so-called "anchor babies"- children born to undocumented immigrants in the United States who, by that birth, become US citizens and provide, by the logic of these laws' proponents, an anchor by which undocumented immigrants may remain in the United States. ${ }^{11}$ Whatever view one takes on this specific issue, it is clear that there is a significant population of undocumented immigrants in the United States with at least one US citizen child. "Almost 9 million people live in families with at least one unauthorized immigrant. Included in the population of unauthorized immigrants are 3.8 million parents of US citizen children. Parents of US citizen children, therefore, make up $37 \%$ of the adult population of unauthorized immigrants." 12 As the issue currently stands, the main focus is on the removal of non-citizen parents who have citizen children and to what extent the interests of those children should affect the removability of the parents. Thus, the subject of the instant article is on how the interests of citizen children should weigh in the balance of determining whether a non-citizen parent or parents should be removed.

Rather than approach the issue solely from the perspective of US immigration law and policy, this article offers a comparative assessment of US domestic law and policy with that of the United Kingdom. This approach is well-founded in general considerations, including the fact that the US and UK have a shared common-law history, have risen to similar levels of economic development, are devoted to rule-of-law principles, and are both attractive destinations for immigrants seeking a better life. More specifically, the comparison is apt because the US and UK immigration systems share the same broad baseline considerations in determining the best interests of citizen children in adjudicating the immigration claims of their non-citizen parents. ${ }^{13}$ Nonetheless, the approach of each country in weighing those considerations is quite distinct, as the subsequent sections of this article will make clear. In considering the differences in approach between these two countries, one can glean both what works and areas of improvement in each system, thereby leading to a synthesis that includes the best of each approach.

Part I provides a brief sketch of UK immigration law and addresses the recent landmark decision of the UK Supreme Court in $\mathrm{ZH} v$. Secretary of State for

justify the Supreme Court revisiting and reversing its prior interpretation of the citizenship clause).

11. See Stephen H. Legomsky, Portraits of the Undocumented Immigrant: A Dialogue, 44 GA. L. REV. 65, 86 n.52 (2009) (citing 'Anchor' Babies: No More U.S. Citizenship, Bus. WK., http://www.businessweek.com/debateroom/archives/2009/07/anchor_babies_no_more_us_citizenshi p.html (last visited Oct. 8, 2009)); Priscilla Huang, Anchor Babies, Over-Breeders, and the Population Bomb: The Reemergence of Nativism and Population Control in Anti-Immigration Policies, 2 HARV. L. \& POL'Y REV. 385, 400-01 (2008).

12. David B. Thronson, Thinking Small: The Need for Big Changes in Immigration Law's Treatment of Children, 14 U.C. DAVIS J. JUV. L. \& POL'Y 239, 244 (2010) (citing Jeffrey S. Passel \& D'Vera Cohn, A Portrait of Unauthorized Immigrants in the United States, PEW HisPaniC CENTER, 8 (Apr. 14, 2009), http://pewhispanic.org/files/reports/107.pdf).

13. See infra Part IV. 
the Home Department. That decision holds that the best interests of the citizen child are a primary consideration in determining whether the United Kingdom can remove a non-citizen consistent with its obligations under the European Convention on Human Rights. ${ }^{14}$ By prioritizing the interests of citizen children in the removal proceedings of their parents, $\mathrm{ZH}$ serves as the template for future cases raising such issues. Part II addresses US immigration law on the removability of non-citizens and the potential avenues for relief from removal to which they may turn. Contrary to the claims of most critics of the prevailing interpretation of the Fourteenth Amendment, US citizen children do not provide an effective "anchor" for non-citizen parents in the United States. This review will make clear that not only does a citizen child not provide an automatic trump to the removal of a non-citizen parent, but also the fact of having such a child rarely gives rise to actual relief from removal. Finally, Part III offers pros and cons regarding the approaches taken by the United Kingdom and the United States, and Part IV attempts to synthesize the best parts of each approach in proposing a new framework for weighing the interests of citizen children confronted with removal of a non-citizen parent.

The competing interests in this issue are weighty and the best framework is likely to leave all parties unhappy in some respects. Nonetheless, there are ways to balance these interests effectively and equitably while also ensuring strict enforcement and compliance with the US immigration system. Moreover, the US government seems ready to accept more balancing of interests in immigration decisions: recently, the Obama administration emphasized the discretionary nature of the Department of Homeland Security's enforcement authority, which supports the feasibility of taking a more nuanced approach in circumstances where the removal of a non-citizen parent implicates his or her citizen children. ${ }^{15}$

II.

\section{REMOVIng Non-Citizen PARENTS OF CITIZEN CHILDREN:} THE UK APPROACH

The United Kingdom's main domestic immigration statute is the $1971 \mathrm{Im}$ migration Act, as amended. ${ }^{16}$ Section 3 of the Act contains two provisions relating to the removability of non-citizens from the United Kingdom. First, "[a] per-

14. ZH v. Sec'y of State for the Home Dep't, [2011] UKSC 4.

15. See Memorandum from John Morton, Immigration and Customs Enforcement, "Exercising Prosecutorial Discretion Consistent with the Civil Immigration Enforcement Priorities of the Agency for the Apprehension, Detention, and Removal of Aliens (Jun. 17, 2011), http://www.nilc.org/immlawpolicy/arrestdet/prosecutorial-discretion-J-Morton-2011-06-17.pdf; see also Damien Cave, Crossing Over, and Over, N.Y. TIMES, Oct. 3, 2011, at A1 (discussing the Obama administration's shift to "surgical" deportations relying on the exercise of discretion in the institution of removal proceedings).

16. Immigration Act, 1971, c. 77 (U.K.). 
son who is not a British citizen is liable to deportation from the United Kingdom if - (a) the Secretary of State deems his deportation to be conducive to the public good; or (b) another person to whose family he belongs is or has been ordered deported." 17 Second, "a person who is not a British citizen shall also be liable to deportation from the United Kingdom if, after he has attained the age of seventeen, he is convicted of an offence for which he is punishable with imprisonment and on his conviction is recommended for deportation by a court empowered by this Act to do so."18 If a non-citizen is liable to deportation, the Secretary of State for the Homeland may order him deported. ${ }^{19}$ Nonetheless, "[a] deportation order against a person may at any time be revoked by a further order of the Secretary of State, and shall cease to have effect if he becomes a British citizen." 20

ZH's case came before the administrative agency and UK courts via an article 8 application to enforce the "[r]ight to respect for private and family life" under the European Convention on Human Rights. ${ }^{21}$ Article 8 provides:

1. Everyone has the right to respect for his private and family life, his home and correspondence.

2. There shall be no interference by a public authority with the exercise of this right except such as is in accordance with the law and is necessary in a democratic society in the interests of national security, public safety or the economic wellbeing of the country, for the prevention of disorder or crime, for the protection of health or morals, or for the protection of the rights and freedoms of others.

Article 8 is enforceable in the UK's domestic administrative agencies and courts via the Human Rights Act of $1998 .^{22}$ For the UK Supreme Court, the issue in $Z H$ had both general and specific dimensions. The "over-arching issue" was the "weight to be given to the best interests of children who are affected by the decision to deport one or both of their parents from this country." ${ }^{23}$ However, the Court saw within this issue a much more specific question: "[I]n what circumstances [was] it permissible to remove or deport a non-citizen parent where the effect will be that a child who is a citizen of the United Kingdom will also have to leave?"24

17. $I d$. at $\S 3(5)$.

18. Id. at $\S 3(6)$.

19. Section 5(1) of the Immigration Act provides that, as to a person liable to deportation under sections 3(5) and 3(6) of the Act, "the Secretary of State may make a deportation order against him, that is to say an order requiring him to leave and prohibiting him from entering the United Kingdom; and a deportation order against a person shall invalidate any leave to enter or remain in the United Kingdom given him before the order is made or while it is in force." $I d$. at $\S 5(1)$.

20. Id. at $\S 5(2)$.

21. Convention for the Protection of Human Rights and Fundamental Freedoms, Nov. 4, 1950, Europ.T.S. No. 5; 213 U.N.T.S. 221. (2009).

22. See Hugh King, Unraveling the Extraterritorial Riddle, 7 J. INT'L CRIM. JUST. 633, 633

23. ZH v. Sec'y of State for the Home Dep 't, [2011] UKSC 4, [1].

24. Id. 
$\mathrm{ZH}$, a female Tanzanian citizen and national, arrived in the United Kingdom in December 1995, where she met a British citizen with whom she had two children - a daughter, born in 1998, and a son, born in 2001. Both children were British citizens because they were born in the United Kingdom and had a British citizen father. ${ }^{25}$ Between 1997 and 2000, the British Government denied ZH asylum three times, once in an application under her own name and twice in applications filed with false identities. In 2001, ZH filed an initial article 8 application with the administrative immigration tribunal, but the tribunal denied her application and dismissed her appeal. ${ }^{26}$ In 2004, ZH applied for leave to remain in the United Kingdom pursuant to the "one-off family concession," but the immigration tribunal denied this application in 2006 due in large part to her prior fraudulent asylum claims. ${ }^{27}$ Before the disposition of that application, $\mathrm{ZH}$ also applied to remain in the United Kingdom pursuant to the "seven year child" concession, but the immigration tribunal denied her application, again based on her fraudulent asylum claims. ${ }^{28}$ In 2005 , while $\mathrm{ZH}$ was pursuing these various applications, she and the children's father separated, but he continued to see the children regularly, visiting each month for about a week. However, he was diagnosed with human immunodeficiency virus ("HIV") in 2007. At the time of ZH's proceedings, he was living with his parents and current wife on disability allowance and was "reported to drink a great deal." 29

Following the father's diagnosis, ZH again sought to forestall her removal via an article 8 application, but she was unsuccessful before the immigration judge. Subsequently, a senior immigration judge granted reconsideration of ZH's claim and found that the initial immigration judge failed to consider adequately the children's British citizenship or to take "into account the rights of the children and the effect of the mother's removal upon them." 30

Nonetheless, after considering the evidence, the senior immigration judge

25. Id. at [2].

26. Id. at [5].

27. Id. See generally UK Border Agency, Apu notice: One-Off Exercise To Allow Families Who Have Been In The UK For Three Or More Years To Stay, 2004, 4/2003 (U.K.),

http://www.ukba.homeoffice.gov.uk/sitecontent/documents/policyandlaw/asylumpolicyinstructions/a punotices/oneoffexercise.pdf?view=Binary (discussing the "one-off family concession," which allowed families who had been in the UK for three or more years to stay when certain eligibility criteria were met).

28. ZH, [2011] UKSC 4 at [5]. The colloquially termed "seven year child concession" was a policy implemented in order to determine "whether enforcement action should proceed or be initiated against parents of a child who was born [in the UK] and has lived continuously to the age of seven or over, or where, having come to the UK at an early age, they have accumulated seven years or more continuous residence." See 485 PARL. DEB., H.C. (6th series) (2008) 49 (U.K.), http://www.publications.parliament.uk/pa/cm200809/cmhansrd/cm081209/wmstext/81209m0002.ht

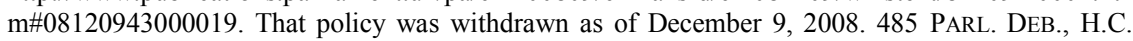
(6th series) (2008) 49 (U.K).

29. ZH, [2011] UKSC 4 at [3].

30. Id. at [6]. 
upheld ZH's removal as proportionate. ${ }^{31}$ The judge recognized that ZH's removal would place a heavy burden on the children's relationship with one of their parents: if the children accompanied ZH to Tanzania, it would "substantially interfere" with their relationship with their father; if the children remained with their father in the United Kingdom, it would "substantially interfere" with their relationship with their mother. ${ }^{32}$ Nevertheless, he concluded that ZH's removal was not a disproportionate response to her unlawful presence for three reasons. First, the judge emphasized that $\mathrm{ZH}$ was "seriously lacking in credibility ${ }^{33}$." Second, he considered ZH's pregnancies irresponsible given her precarious immigration status in the United Kingdom and viewed the current dilemma as a foreseeable result of the couple's prior choices. ${ }^{34}$ Third, he found that the children could live with either parent without practical difficulty-essentially ignoring the father's HIV status and financial difficulties. ${ }^{35}$ Given the above factors and the general imperative of immigration control, the judge found that an interference with the children's family life did not outweigh the importance of removing $\mathrm{ZH}^{36}$

The Court of Appeal for England and Wales upheld this decision. Counsel for ZH argued that the children's citizenship acted as a "trump card", prohibiting their mother's removal. ${ }^{37}$ The court rejected this proposition as too absolutist and inconsistent with governing law. ${ }^{38}$

Before the UK Supreme Court, counsel for ZH retreated from the absolutist position presented before the Court of Appeal and argued simply "that insufficient weight [was] given to the welfare of all children affected by decisions to remove their parents and in particular to the welfare of children who are British citizens." 39 The Secretary of State decided that ZH's removal would be disproportionate but questioned what the appropriate governing principles would be in cases where the removal of non-citizen parents had the potential to affect citizen children.

The opinion of the Court began by reciting the appropriate standards by which to adjudicate an article 8 application. In such an application the authorities are required to consider the rights of all potentially affected family members, not just the specific applicant herself. ${ }^{40}$ In the words of Lady Hale:

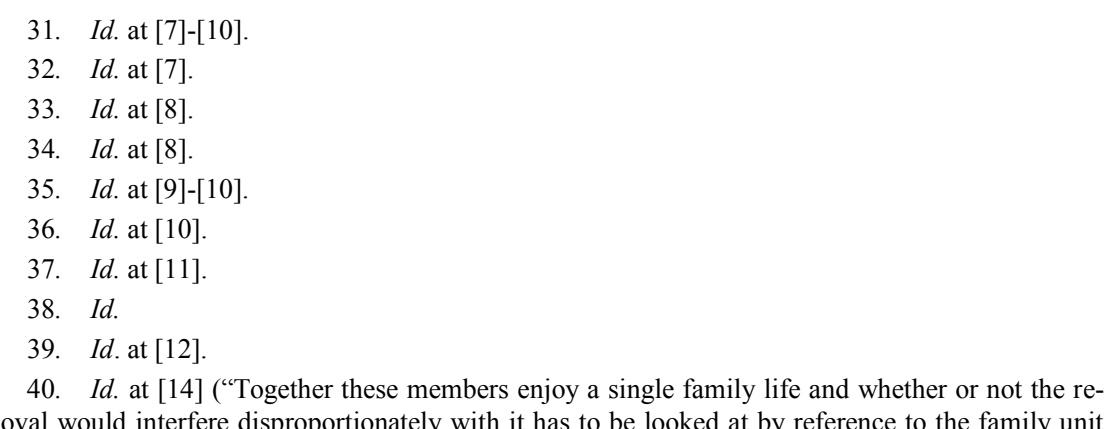
moval would interfere disproportionately with it has to be looked at by reference to the family unit 
The decision-maker has to balance the reason for the expulsion against the impact upon other family members, including any alternative means of preserving family ties. The reason for deporting may be comparatively weak, while the impact on the rest of the family, either of being left behind or of being forced to leave their own country, may be severe. On the other hand, the reason for deporting may be very strong, or it may be entirely reasonable to expect the other family members to leave with the person deported. ${ }^{41}$

Thus, the determination of an article 8 application is intricately tied to the specific facts and circumstances of the applicant. ${ }^{42}$ Nonetheless, the Court noted that such applications generally arise in one of two circumstances: (1) where the non-citizen is a long-settled resident of a country and has committed a criminal offense that subjects him to removal or (2) "where a person is to be removed because he or she has no right to be or remain in the country."43 ZH's case fell under the second situation, as it was her illegal presence alone that subjected her to the possibility of removal.

According to the European Court of Human Rights (ECtHR), in an article 8 proceeding, a national court must decide whether the removal of a non-citizen will interfere with "the right to respect for family life." If so, the removal must be "necessary in a democratic society and proportionate to the legitimate aim pursued." 44 In making this determination, the starting point for the state authorities and the reviewing courts "is the right of all states to control the entry and residence of aliens." The state's legitimate aim likely will be "the economic well-being of the country in controlling immigration, although the prevention of disorder and crime and the protection of the rights and freedoms of others may also be relevant." 45 Other pertinent factors include the length of the applicant's stay in the country from which he or she is to be expelled; the concerned persons' nationalities; the applicant's family situation, including the length and closeness of any marriage; whether there are children from their marriage and their ages; whether family life was established knowing the precariousness of the immigration situation; and the difficulties attendant upon the applicant's removal to and life in the country of nationality. ${ }^{46}$ Finally, and most pertinent to this inquiry, authorities must consider "the best interests and well-being of the children," specifically the children's potential difficulties in the applicant's destination country and the "solidity of social, cultural and family ties" with both

as a whole and the impact of removal upon each member. If overall the removal would be disproportionate, all affected family members are to be regarded as victims.") (quoting Beoku-Betts v. Sec 'y of State for the Home Dep 't, [2008] UKHL 39, [20]).

41. Naidike v. Att'y Gen. of Trin. \& Tobago, [2004] UKPC 49, [75].

42. EB v. Sec'y of State for the Home Dep't, [2008] UKHL 41, [12] ("Thus the appellate immigration authority must make its own judgment and that judgment will be strongly influenced by the particular facts and circumstances of the particular case.").

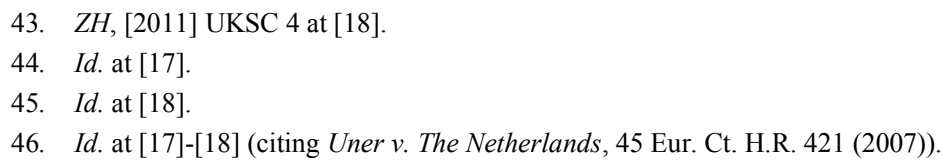


the host country and the destination country. ${ }^{47}$

Despite the ostensibly strict standard of review of article 8 applications, the ECtHR has found violations of article 8 even in egregious cases of illegal presence with children involved. For instance, in Rodrigues da Silva Hoogkamer v. The Netherlands, the ECtHR found a Brazilian mother's expulsion from the Netherlands disproportionate, despite the fact that she started her family in full knowledge of her illegal presence. ${ }^{48}$ In $Z H$, the UK Supreme Court explained the ECtHR's article 8 decisions as a response to increasing international awareness of the importance of children's rights in making legal determinations under both international and domestic law. ${ }^{49}$ The United Kingdom is party to the United Nations Convention on the Rights of the Child, and that instrument requires that "[i]n all actions concerning children . . . the best interests of the child shall be a primary consideration." 50 The United Kingdom implemented this obligation into domestic law via the Borders, Citizenship and Immigration Act, which provides that all immigration determinations must "regard . . . the need to safeguard and promote the welfare of children who are in the United Kingdom." 51

In addition to reviewing relevant ECtHR decisions and United Nations ("UN") documents, the UK Supreme Court also looked at case law from other countries. The Court cited with approval the Federal Court of Australia's reasoning in a similar case:

[The Tribunal] was required to identify what the best interests of Mr. Wan's children required with respect to the exercise of its discretion and then to assess whether the strength of any other consideration, or the cumulative effect of other considerations, outweighed the consideration of the best interests of the children understood as a primary consideration. ${ }^{52}$

In its reliance on this case, the UK Supreme Court put forth its belief that the best interests of the children must be considered first, but other considerations could outweigh it in determining the proportionality of removal. ${ }^{53}$ Having examined the ECtHR decisions, UN documents and foreign case law, the UK Supreme Court ultimately concluded that the best interests of the child are $a$ primary consideration, but not the primary consideration, in a removability proceeding. ${ }^{54}$

Having established that the best interests of the child will be a primary consideration in determining a non-citizen parent's removal, the UK Supreme Court

47. Id. at [17] (citing Uner, 45 Eur. Ct. H.R. 421).

48. Rodrigues da Silva Hoogkamer v. The Netherlands, 44 Eur. Ct. H.R. 729 (2006).

49. See ZH, [2011] UKSC 4 at [21]-[28].

50. Convention on the Rights of the Child, G.A. Res. 44/25, art. 3(1), U.N. Doc. A/RES/44/25 (Nov. 20, 1989).

51. Borders, Citizenship and Immigration Act, 2009, c. 11, § 55(1)(a) (U.K.).

52. Wan v. Minister for Immigration \& Multicultural Affairs [2001] FCA 568, \32 (Austl.).

53. $Z H$, [2011] UKSC 4 at [26].

54. Id. at [29]-[33]. 
then identified what is encompassed by the phrase "best interests of the child." According to the Court, this standard required asking "whether it [was] reasonable to expect the child to live in another country." 55 To answer this question, the Court listed several relevant factors: the level of the child's integration in his present country and the length of absence from the other country; living and caretaking arrangements in the other country; and the strength of the child's relationships with parents or other family members which would be severed if the child moved away." 56 The Court noted that the nationality of the children will be an important factor in gauging the children's best interests even if citizenship will not operate as a "trump card" against the parent's removal. ${ }^{57}$

Applying these principles to the facts of the case, the Court noted that both of ZH's children were British citizens by birth and descent and that "they ha[d] an unqualified right of abode" in the United Kingdom. ${ }^{58}$ They had lived in Britain, were receiving a British education, had social ties to Britain, and had a positive relationship with their father. ${ }^{59}$ As British citizens, the children had rights which "they w[ould] not be able to exercise if they move[d] to another country." ${ }^{\circ 0}$ The Court then examined whether the children's interests, while a primary consideration, could be "outweighed by the cumulative effect of other considerations." ${ }^{61}$ The Court acknowledged numerous factors that weighed against $\mathrm{ZH}$, namely "the need to maintain firm and fair immigration control ... [ZH's] appalling immigration history and the precariousness of her position when family life was created." ${ }^{2}$ Nonetheless, the Court found that "there really [was] only room for one view," as the children would have had to leave the United Kingdom with their mother based on a legal transgression for which they bore no responsibility. ${ }^{63}$ Accordingly, the Court allowed ZH's appeal, and thus forestalled her deportation. ${ }^{64}$

Lord Hope's and Lord Kerr's concurring opinions further emphasized the child's interests in UK deportation proceedings. ${ }^{65}$ In his opinion, Lord Hope

55. Id. at [29].

56. Id.

57. See id. at [30] ("Although nationality is not a 'trump card' it is of particular importance in assessing the best interests of any child.").

58. Id. at [31].

59. Id.

60. Id. at [32].

61. Id. at [33].

62. Id.

63. Id. (quoting Simon Brown L.J. in Edore v. Sec'y of State for the Home Dep't [2003] 1 WLR 2979, [26]).

64. Id. at [38]. The Court also established the possibility that the government should directly consult the children in certain circumstances regarding their interests in specific cases. Id. at [34][37].

65. Id. at [39] (opinion of Lord Hope); Id. at [45] (opinion of Lord Kerr). 
took aim at two errors he perceived in the decision of the Court of Appeals. ${ }^{66}$ First, although he agreed that the Court properly rejected the assertion that a child's citizenship will trump the state's interest in the removal of a non-citizen parent, he argued that it nonetheless failed to correctly weigh the fact of citizenship. According to Lord Hope, citizenship may not be a trump, but:

[I]t will hardly ever be less than a very significant and weighty factor against moving children who have that status to another country with a parent who has no right to remain here, especially if the effect of doing this is that they will inevitably lose those benefits and advantages for the rest of their childhood. ${ }^{67}$

Second, both the administrative tribunal and the Court of Appeals examined the interference with the family unit in light of the mother's own immigration transgressions, while " $[t]$ he best interests of the children melted away into the background." 68 Lord Hope explained that neither consideration would be dispositive: weighing both factors together would dictate the outcome of the removal proceeding:

There is an obvious tension between the need to maintain a proper and efficient system of immigration control and the principle that, where children are involved, the best interests of the children must be a primary consideration ... The fact that the mother's immigration status was precarious when they were conceived may lead to a suspicion that the parents saw this as a way of strengthening her case for being allowed to remain here. But considerations of that kind cannot be held against the children in this assessment. It would be wrong in principle to devalue what was in their best interests by something for which they could in no way be held responsible. ${ }^{69}$

Lord Kerr's opinion went further in its deference to the child's interests. $\mathrm{He}$ believed that the best interests of the child should dictate the ultimate disposition of a given case unless there were substantial countervailing considerations-in essence, the best interests would create a rebuttable presumption against the removal of a non-citizen parent. ${ }^{70}$

Succinctly distilled, the UK Supreme Court concluded that the interests of citizen children should play a role in determining whether removal of a noncitizen parent would be appropriate. It also deemed those interests to be "a primary consideration" in weighing the competing interests. Finally, the Court held that a determination of the best interests of the child should not lead inexorably to a disposition in line with those interests and that other considerations could conceivably outweigh the "best interests" of the child. Although there is much in the language of the Court's decision to recommend this framework in the context of removing non-citizen parents with citizen children, the Court undercut its own statement of the rule in its application thereof.

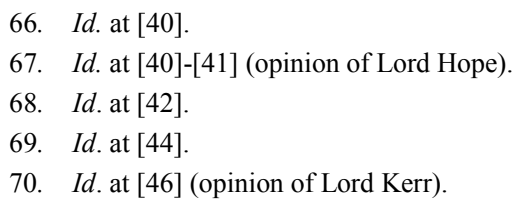


The Court forcefully asserted that the child's citizenship will not act as a trump against removal, but it is hard to conceive of any alternative in the context of the Court's holding in ZH's case. ZH filed at least two fraudulent asylum claims. ${ }^{71}$ She gave birth to two children in the United Kingdom after the British Government rejected her claims to status and notwithstanding the reality that there were no avenues available to her through which to normalize her status. It would be hard to imagine a situation where the abuses of the applicant are greater than in the instant case. It is hard to believe that, aside from her children's citizenship, her removal would not be proportionate. The health status of the father and his precarious living situation could explain why the children's remaining in the United Kingdom would be an unreasonable prospect. The United Kingdom viewed him as unable provide the appropriate level of care given his own health issues. Yet that factor alone does little to undercut the likelihood of the children having to depart with their mother. In short, based on the Court's decision in $\mathrm{ZH}$, it seems that the child's citizenship will be determinative, even though the Court went to great pains to refute or restrict that assertion.

To be sure, beyond this critique there are perhaps open issues left in the decision's wake. First, what if both parents are removable as non-citizens? If citizenship is not to act as a trump and the family would remain intact after removal, it seems that other factors would outweigh the best interests of the citizen children. Early in its opinion, the Court noted a pending case presenting such facts. ${ }^{72}$ Accordingly, the courts may resolve this issue sooner than later. Second, what if the children are not citizens of the United Kingdom? This will lead to a fact intensive assessment of the children's connections to the United Kingdom, among other considerations. Removing the importance of citizenship, however, even long-term residence would likely not halt deportation proceedings. In any event, these are questions that the UK courts will have to confront in the coming years. $Z H$ provides, at the least, an appropriate framework in which to consider these additional issues.

III.

REMOVING NON-CITIZEN PARENTS OF CITIZEN CHILDREN: THE US APPROACH

Whereas the previous section dealt with UK immigration law and policy, this section examines US immigration law and policy as it relates to the deportation of non-citizens. US immigration law is codified in the Immigration and Nationality Act of 1952 ("INA"), as amended. Non-citizens may be subject to deportation proceedings in the United States because they are either inadmissible or deportable under sections 212 and 237, respectively, of the INA. ${ }^{73}$ The for-

71. Id. at [5].

72. Id. at [4].

73. Immigration and Nationality Act (INA) § 212, 8 U.S.C. § 1182 (2006); 8 U.S.C. $\S 1227$ 
mer applies to aliens seeking lawful admission to the United States, whereas the latter applies to aliens who have been admitted or are otherwise already present in the United States. ${ }^{74}$ If the US Government successfully establishes that an alien meets the criteria for inadmissibility or deportability, the alien is then placed in removable status regardless of whether they may have US citizen children. ${ }^{75}$ In other words, the sole consideration at this stage is whether the alien falls within the inadmissibility or deportability criteria of the INA.

Nonetheless, the INA does provide that otherwise removable aliens may apply for certain waivers. Some of these waivers are available only for spouses and children of US citizens, thus excluding parents of US citizens. For instance, if an alien is inadmissible under INA section 212(a)(6)(C)(i) for seeking to procure or procuring a US visa, immigrant documentation, or admission "by fraud or willfully misrepresenting a material fact," $" 76$ he may apply for a waiver under INA section 212(i)(1) if he is "the spouse, son, or daughter of a United States citizen or of an alien lawfully admitted for permanent residence" and "it is established to the satisfaction of the Attorney General that the refusal of admission ... of such immigrant alien would result in extreme hardship to the citizen or lawfully resident spouse or parent[.]"77 Other waivers are available without regard to whether the non-citizen alien has a qualifying relationship with a US citizen. For example, INA sections 212(d)(11) and 237(a)(1)(E)(iii) provide for waivers if the Attorney General charges the alien with smuggling, provided that "the alien has encouraged, induced, assisted, abetted, or aided only an individual who at the time of such action was the alien's spouse, parent, son, or daughter[.]"78 The imperative behind these waivers, as with other relief provisions of the INA, is family unity. ${ }^{79}$

For other waivers, the fact that a non-citizen parent may have a US citizen child will be a factor in determining his eligibility for such a waiver. In such circumstances, the importance of this qualifying relationship may trump otherwise compelling interests in the removal of the non-citizen parent. For instance, under the INA, "[a]ny immigrant who is or has been a member of or affiliated with the Communist or any other totalitarian party ... domestic or foreign" is inadmissible. ${ }^{80}$ Nonetheless, the Attorney General may waive this provision if the immigrant "is the parent, spouse, son, daughter, brother, or sister of a citizen of the

(2006); see also Stephen H. Legomsky, Restructuring Immigration Adjudication, 59 DUKE L.J. 1635,1642 (2010).

74. 8 U.S.C. $\S 1227$.

75. See id. $\S 1229 \mathrm{a}(\mathrm{a})(1),(\mathrm{c})(3) ; 8$ C.F.R. $\S 1240.8$ (2010).

76. 8 U.S.C. $\$ 1182(\mathrm{a})(6)(\mathrm{C})(\mathrm{i})$.

77. Id. $\S 1182(\mathrm{i})(1)$.

78. Id. $\S \S 1182(\mathrm{~d})(11), 1227(\mathrm{a})(1)(\mathrm{E})(\mathrm{iii}) ;$ see also Batista v. Gonzales, 494 F.3d 67 (2d Cir. 2007) (addressing eligibility for a waiver under INA $\S 212(d)(1)$ ).

79. See, for example, 8 U.S.C. § 1182(d)(11) ("The Attorney General may, in his discretion for humanitarian purposes, to assure family unity ....").

80. Id. $\S 1182(\mathrm{a})(3)(\mathrm{D})(\mathrm{i})$. 
United States . . for humanitarian purposes, to assure family unity, or when it is otherwise in the public interest if the immigrant is not a threat to the security of the United States." ${ }^{81}$ The Attorney General may deem an alien inadmissible if they have "a communicable disease of public health significance." 82 The Attorney General may waive this ground "in the case of an alien who . . has a son or daughter who is a United States citizen[.]" ${ }^{13}$ Criminal convictions, involvement in criminal schemes, and intent to engage in illegal activities if admitted to the United States are encompassed by numerous grounds of inadmissibility and removability. ${ }^{84}$ The INA nonetheless provides certain waivers even in cases of criminality. The Attorney General, however, may waive certain criminal grounds of inadmissibility "in the case of an immigrant who is the spouse, parent, son, or daughter of a citizen of the United States . . . if it is established to the satisfaction of the Attorney General that the alien's denial of admission would result in extreme hardship to the United States citizen ... spouse, parent, son, or daughter." $" 85$ If the US Government deems that an alien within the United States is removable on account of being inadmissible at the time of his admission, the alien may obtain a waiver from the Attorney General if he or she is "the spouse, parent, son, or daughter of a citizen of the United States," assuming he or she meets other eligibility criteria. ${ }^{86}$

Beyond the statutory exceptions that the Attorney General must make in these types of cases, including discerning whether, in the appropriate cases, the non-citizen has a qualifying relationship with a US citizen, discretionary factors are the most important facet in determining whether waiver should be granted. The Department of Justice Board of Immigration Appeals has the ultimate discretion as to whether to grant or deny a waiver, but as part of that determination the Board must make an initial statutory eligibility determination about whether the removal of the alien will result in "extreme hardship" to a qualifying relative. The Board, however, does not define "extreme hardship" in the context of the preceding waivers. As the Board has written, "extreme hardship is not a definable term of fixed and inflexible meaning, and the elements to establish extreme hardship are dependent upon the facts and circumstances of each case." 87 Nonetheless, in its decision in Matter of Cervantes-Gonzalez, the Board did enumerate certain factors that would be relevant to the determination:

The factors deemed relevant in determining extreme hardship to a qualifying relative include, but are not limited to, the following: the presence of lawful permanent residence or US citizen family ties to this country; the qualifying relative's

81. Id. § 1182(a)(3)(D)(iv).

82. Id. § 1182(a)(1)(A)(i).

83. Id. § $1182(\mathrm{~g})(1)(\mathrm{B})$.

84. See generally id. § 1182(a)(2).

85. Id. § 1182(h)(1)(B).

86. Id. $\S 1227(\mathrm{a})(1)(\mathrm{H})$.

87. In re Cervantes-Gonzalez, 22 I. \& N. Dec. 560, 565 (B.I.A. 1999). 
family ties outside the United States; the conditions in the country or countries to which the qualifying relative would relocate and the extent of the qualifying relative's ties to such countries; the financial impact of departure from this country; and, finally, significant conditions of health, particularly when tied to an unavailability of suitable medical care in the country to which the qualifying relative would relocate. ${ }^{88}$

Discerning whether a US citizen child would face extreme hardship upon the removal of a non-citizen parent provides one basis by which to weigh the best interests of that child. In Matter of Cervantes-Gonzalez, the Board did not find extreme hardship, but that case did not involve a US citizen child. ${ }^{89}$ The only qualifying relative in that case was the alien's citizen spouse; they married during the course of removal proceedings, she was a native Mexican and could thus easily acclimate to life in Mexico, there were no financial ties to the United States, and the wife made no claim that she would suffer extreme hardship if her alien spouse was removed. ${ }^{90}$ In Matter of Kao \& Lin, the Board did find that the removal of non-citizen parents would result in extreme hardship to at least one of their US citizen children. ${ }^{91}$ The husband and wife applicants in that case were Taiwanese, had lived in the United States for 19 and 17 years, respectively, and had five US citizen children who were not fluent in Chinese. ${ }^{92}$ The Board found "nothing in the record to indicate that [the children's] language capabilities ... [were] sufficient for an adequate transition to daily life in Taiwan." 93 Moreover, the Board emphasized that the children "ha[d] lived their entire lives in the

88. Id. at 565-66; see also 8 C.F.R. $\S 1240.58$ (b) (2010) (relating to the repealed relief of suspension of deportation) ("To establish extreme hardship, an applicant must demonstrate that deportation would result in a degree of hardship beyond that typically associated with deportation. Factors that may be considered in evaluating whether deportation would result in extreme hardship to the alien or to the alien's qualified relative include, but are not limited to, the following: (1) The age of the alien, both at the time of entry to the United States and at the time of application for suspension of deportation; (2) The age, number, and immigration status of the alien's children and their ability to speak the native language and to adjust to life in the country of return; (3) The health condition of the alien or the alien's children, spouse, or parents and the availability of any required medical treatment in the country to which the alien would be returned; (4) The alien's ability to obtain employment in the country to which the alien would be returned; (5) The length of residence in the United States; (6) The existence of other family members who are or will be legally residing in the United States; (7) The financial impact of the alien's departure; (8) The impact of a disruption of educational opportunities; (9) The psychological impact of the alien's deportation; (10) The current political and economic conditions in the country to which the alien would be returned; (11) Family and other ties to the country to which the alien would be returned; (12) Contributions to and ties to a community in the United States, including the degree of integration into society; (13) Immigration history, including authorized residence in the United States; and (14) The availability of other means of adjusting to permanent resident status.").

89. In re Cervantes-Gonzalez, 22 I. \& N. Dec. at 566.

90. Id. at 566-68.

91. In re Kao \& Lin, 23 I. \& N. Dec. 45, 51 (B.I.A. 2001) (on application for suspension of deportation).

92. Id. at 46,50 .

93. Id. at 50 . 
United States and [were] completely integrated into their American lifestyles. Their needs for housing, food, clothing, education, and community support ha[d] been adequately met." 94 As a result, the Board was "satisfied that to uproot the oldest daughter . . . at this stage in her education and social development and to require her to survive in a Chinese-only environment would [have been] a significant disruption that would constitute extreme hardship." 95

To establish eligibility for a waiver of inadmissibility or deportability, the alien must demonstrate not only statutory eligibility, including extreme hardship to a qualifying relative, but also that the waiver "is warranted in the exercise of discretion." 96 Thus, even if statutory criteria are met, the Board may deny the alien's waiver application. In determining whether a waiver is justified, the adjudicator considers the adverse and positive factors in the specific case, ${ }^{97}$ thus providing a second opportunity to weigh the best interests of citizen children. Adverse factors include "the nature and underlying circumstances of the exclusion ground at issue, the presence of additional significant violations of this country's immigration laws, the existence of a criminal record and, if so, its nature, currency and seriousness, and the presence of other evidence indicative of an alien's bad character or undesirability as a permanent resident of this country." $"$ Favorable considerations include:

family ties in the United States, residence of long duration in this country (particularly where the alien began his residency at a young age), evidence of hardship to the alien and his family if he is excluded and deported, service in this country's Armed Forces, a history of stable employment, the existence of property or business ties, evidence of value and service to the community, evidence of genuine rehabilitation if a criminal record exists, and other evidence attesting to the alien's good character. ${ }^{99}$

In weighing these adverse and positive factors, the adjudicator must take into account the "underlying significance" of these factors ${ }^{100}$ :

[I]f the alien has relatives in the United States, the quality of their relationship must be considered in determining the weight to be awarded this equity. Further, the equity of a marriage and the weight given to any hardship to the spouse is diminished if the parties married after the commencement of deportation proceedings, with knowledge that the alien might be deported. ${ }^{101}$

In Matter of Mendez-Moralez, the Board upheld the denial of a waiver of inadmissibility under INA section 212(h)(1)(B) despite the fact that Mendez-

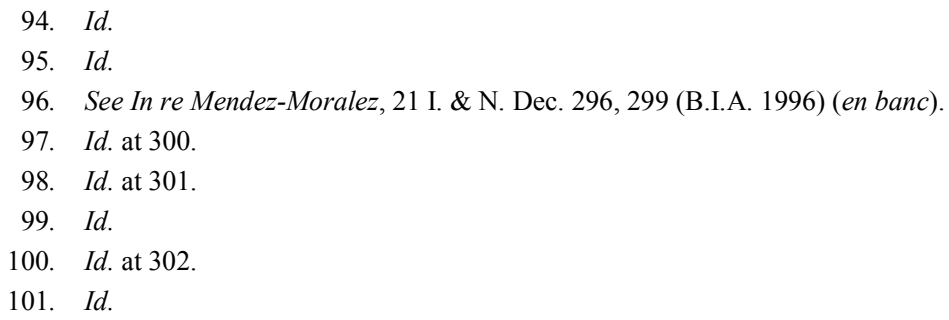


Moralez had a citizen wife, three citizen children, two lawful permanent resident brothers, lawful permanent resident parents, and supported his family financially, because it found that adverse factors - the seriousness of his conviction for sexual assault of a minor and his lack of rehabilitation - outweighed these equities. ${ }^{102}$

Thus, although the Justice Department's determination of removability of a non-citizen parent will not make reference to any US citizen children that the alien parent may have, the existence of such children may influence the Department's ultimate inadmissibility or deportation determination. In making that decision, the INA permits the adjudicator to assess and weigh the best interests of the citizen child at two points, first at the threshold level of determining statutory eligibility, and second if and when the adjudicator exercises his or her discretion in granting the alien parent a waiver.

In addition to waivers of inadmissibility or deportability, the INA also provides various forms of relief, some of which are conditioned on a non-citizen possessing a qualifying relationship with a US citizen. This article focuses on two forms of relief: (i) status adjustment and (ii) cancellation of deportation proceedings for certain non-lawful permanent residents.

An alien non-lawful permanent resident in removal proceedings may seek cancellation of removal proceedings. ${ }^{103}$ To establish his eligibility for such relief, he must demonstrate that he has remained in the United States for a continuous period of ten years preceding his application, has good moral character, has not been convicted of certain disqualifying offenses, and "that removal would result in exceptional and extremely unusual hardship to the alien's spouse, parent, or child, who is a citizen of the United States[.]"104 Even if the applicant meets the statutory eligibility criteria, he must still establish that cancellation of removal should be granted in the exercise of discretion. ${ }^{105}$ As with the various waivers discussed above, the focus will often be on if the alien can establish "exceptional and extremely unusual hardship" to a qualifying relative. ${ }^{106}$

The Board has held that the "exceptional and extremely unusual hardship" standard is much higher than the "extreme hardship" threshold required for INA section 212 inadmissibility waivers. ${ }^{107}$ The heightened requirement reflects Congress's intent to limit cancellations of removal proceedings for nonpermanent residents to "truly exceptional cases" where the applicant can demonstrate hardship "'substantially' beyond the ordinary hardship that would be ex-

102. Id. at $302-05$.

103. Immigration and Nationality Act (INA) § $240 \mathrm{~A}(\mathrm{~b})(1), 8$ U.S.C. $\S 1229 \mathrm{~b}(\mathrm{~b})(1)$ (2006).

104. 8 U.S.C. $\S \S 1229 b(b)(1)(A)-(D)$.

105. See id. $\S 1229 \mathrm{~b}(\mathrm{~b})(1)(\mathrm{D})$.

106. Id.

107. See In re Monreal-Aguinaga, 23 I. \& N. Dec. 56, 59 (B.I.A. 2001) (en banc) (citing Cortes-Castillo v. INS, 997 F.2d 1199 (7th Cir. 1993); Brown v. INS, 775 F.2d 383 (D.C. Cir. 1985)). 
pected when a close family member leaves this country." 108 Nonetheless, the factors the agency considers in determining whether removal would result in exceptional and extremely unusual hardship are identical to those utilized in finding extreme hardship: the adjudicator simply weighs the evidence differently in light of the higher burden espoused by the alien seeking relief. ${ }^{109}$

As with the extreme hardship determination, the adjudicator will not consider hardship factors relating to the applicant himself unless such factors also impact or affect the potential hardship to a qualifying relative. ${ }^{110}$ In evaluating the import given to qualifying relatives, the adjudicator should "consider the ages, health, and circumstances" of those relatives. ${ }^{111}$ For example, the Board in Matter of Monreal-Aguinaga opined "an applicant who has elderly parents in this country who are solely dependent upon him for support might well have a strong case. Another strong applicant might have a qualifying child with very serious health issues, or compelling special needs in school."112 Economic issues may also be relevant: "A lower standard of living or adverse conditions in the country of return are factors to consider only insofar as they may affect a qualifying relative, but generally will be insufficient in themselves to support a finding of exceptional and extremely unusual hardship." 113

The Board's reasoning in its decisions illustrates how high a standard "exceptional and extremely unusual hardship" is in practice. In Matter of MonrealAguinaga, the Board found no exceptional and extremely unusual hardship in removing a non-citizen father with three US citizen children, one of whom had already returned to Mexico with the applicant's non-citizen spouse. ${ }^{114}$ The Board found the case sympathetic, noting potential hardships to the school-aged children as well as less opportunities in Mexico for the family. ${ }^{115}$ Nonetheless, it pointed to mitigating factors that prevented a determination of "exceptional and extremely unusual hardship." 116 The Board reasoned that if the applicant was removed and the remaining two US citizen children followed, the nuclear family could be reunited, the applicant could work and support the family in Mexico, the children could understand and communicate in Spanish, and the applicant's US resident parents could survive financially without his assistance. ${ }^{117}$

Similarly, the Board found no exceptional and extremely unusual hardship

108. Id. at 62 .

109. See id. at 63 .

110. Id.

111. Id.

112. Id.

113. Id. at 63-64.

114. Seeid.

115. Id. at 64 .

116. Id. at 63-64.

117. Id. at 58,65 . 
in the case of Matter of Andazola-Rivas. ${ }^{118}$ There, the applicant was a single mother of two school-aged US citizen children, whose entire family lived within the United States. Despite the possibility of separating the alien parent from her family if the Board denied her waiver to halt removal proceedings, it found that the facts, including the health of the children, the possession of significant financial assets, and the diminished educational and economic opportunities available in Mexico were insufficient to demonstrate exceptional and extremely unusual hardship. ${ }^{119}$

The Board did, however, find exceptional and extremely unusual hardship in the case of Matter of Recinas. ${ }^{120}$ Recinas was a single mother with six children, four of whom were US citizens. Her four citizen children had never been to Mexico and did not speak, write, or understand Spanish well. The rest of her family, including two lawful resident parents and five lawful resident siblings, also lived in the United States, and Recinas also operated her own business in the United States. Recinas had no other means to lawfully immigrate to the United States in the near future, and, with no family in Mexico, the children would be entirely dependent on her for financial and emotional support. ${ }^{121}$ The Board concluded that these factors combined to render the hardship in this case "well beyond that which is normally experienced in most cases of removal." 122 In so holding, however, the Board did hold that Recinas' case "present[ed] a close question" and that it "consider[ed] this case to be on the outer limit of the narrow spectrum of cases in which the exceptional and extremely unusual hardship standard will be met."123 Thus, in the absence of facts as sympathetic and compelling as those in Matter of Recinas, the Board is unlikely to grant a waiver to cancel deportation proceedings.

Adjustment of status can also provide non-citizens with effective relief from removal. To adjust status, a US citizen or lawful permanent resident files a visa petition for an alien relative. So long as the petitioner has a qualifying relationship with the alien-beneficiary, the granting of this petition could then lead to the adjustment of status of that alien to a lawful permanent resident. ${ }^{124}$ Visas for qualifying alien relatives are, on the whole, allocated based on a hierarchy of preference categories, which establish when a visa will be available to the alienbeneficiary. ${ }^{125}$ The INA provides, however, that visas are immediately available

118. In re Andazola-Rivas, 23 I. \& N. Dec. 319 (B.I.A. 2002) (en banc).

119. Id. at 320, 323-24.

120. In re Recinas, 23 I. \& N. Dec. 467, 473 (B.I.A. 2002).

121. Id. at 469-71.

122. Id. at 472 .

123. Id. at 470 .

124. See Immigration and Nationality Act (INA) $\S \S 204(a)(1)(A)(i), 245(a), 8$ U.S.C. $\S \S$ 1154(a)(1)(A)(i), 1255(a) (2006); 8 C.F.R. $\S \S ~ 204.1(a), ~ 204.2$ (2010); see generally T. ALEXANDER ALEINIKOFF, ET AL., IMMIGRATION AND CITIZENSHIP: PROCESS AND POLICY 501-04, 515-21 (West, 5th ed. 2003).

125. See 8 U.S.C. $\S \S 1151(a)(1),(c), 1152(a), 1153(a) ; 8$ C.F.R. $\S 204.1(a)$. 
to aliens whose petitions are filed by US citizens, as long as the alienbeneficiary has an "immediate-relative" relationship with the petitioner. ${ }^{126}$ This category, which is not subject to the direct numerical limitations on immigrant visas, encompasses the children, spouse, and parents of a US citizen. ${ }^{127}$ Accordingly, a non-citizen parent could adjust status based on a petition filed by a US citizen child. However, if a parent is the beneficiary of the petition, the petitioner must be at least 21 years of age - that is, a child cannot petition for his parent(s) until he has attained that age. ${ }^{128}$ Thus, although adjustment may provide an avenue by which a non-citizen parent could obtain lawful status in the United States, a potential beneficiary may have to wait for as long as 21 years before his or her child could file a petition, from the birth of the child to his obtaining the age of majority. ${ }^{129}$

To conclude, the INA does provide avenues for a non-citizen to obtain relief from removal by way of parentage of a US citizen child. However, relief can be difficult to obtain, even when the case involves a parent-child relationship. Cancellation of removal involves onerous demonstrations of hardship to the US citizen child, and petitions by the child for the parent's adjustment of status often involve prolonged delay. In short, contrary to the shouts of anchor-baby opponents, who seem to believe the mere fact of having a citizen child will insulate the non-citizen parent from removal, it can hardly be said that the INA will provide ready relief to non-citizen parents of US citizen children.

Furthermore, non-citizen parents have scant opportunity to appeal adverse outcomes. The administrative judgments of the Board and immigration judge are likely to be the last word on the matter, as the INA curtails the courts of appeals' jurisdiction to review discretionary determinations. ${ }^{130}$ The courts of appeals retain jurisdiction to review colorable legal and constitutional challenges, ${ }^{131}$ but this is unlikely to provide a basis for review in most cases, as the substance of the challenge will likely revolve around the agency's weighing of the evidence - an archetypal discretionary determination. ${ }^{132}$

IV.

COMPARING THE AMERICAN AND BRITISH APPROACHES

The United Kingdom and the United States differ in how they approach the

\author{
126. 8 U.S.C. $\S 1151(\mathrm{~b})$. \\ 127. Id. $\S 1151(\mathrm{~b})(2)(\mathrm{A})(\mathrm{i})$. \\ 128. See id. \\ 129. See, for example, id. $\S 1182(\mathrm{a})(9)(\mathrm{A})$ (inadmissibility for a variable term of years for aliens \\ previously ordered removed); INA $\S 212(\mathrm{a})(9)(\mathrm{C}), i d$. $\S 1182(\mathrm{a})(9)(\mathrm{C})$ (inadmissibility for certain \\ aliens unlawfully present in the United States after prior immigration violations). \\ 130. See id. §1252(a)(2)(B). \\ 131. Id. § 1252(a)(2)(D). \\ 132. See, for example, Solis v. Holder, 647 F.3d 831 (8th Cir. 2011).
}


removability of non-citizen parents in light of the "best interests" of citizen children. These differences are highlighted by three principal considerations: (1) the different weight each country gives to the child's citizenship in removal determinations; (2) the characterization of how removal proceedings impact the child's interests; and (3) the differing legal regimes and international obligations in each country.

First, the United Kingdom places greater importance on a child's citizenship than does the United States in a parent's removal proceedings. In $Z H$, the child's British citizenship was overwhelmingly the most important factor in finding the removability of ZH disproportionate. Given the facts of ZH's case, the children's citizenship effectively functioned as a trump card despite the UK Supreme Court's statement to the contrary. ${ }^{133}$ Even under the Court's explicit analysis, the citizenship of children will be a very significant factor in determining the removability of the non-citizen parent, a fact in large part driven by that country's treaty obligations. ${ }^{134}$

The United States, in contrast, places less weight on a child's citizenship in establishing both the removability of the non-citizen parent and whether that parent qualifies for a waiver or some other form of relief from removal. The US Government does not deem a parent's removal as an infringement on any of the citizen child's constitutional rights by virtue of their citizenship. As the US Court of Appeals for the First Circuit recently held, "[t]he circuits that have addressed the constitutional issue ... have uniformly held that a parent's otherwise valid deportation does not violate a child's constitutional right." 135 In the words of the First Circuit:

If what were happening here was conscience shocking by contemporary American standards, the lack of precedent would not bar a new departure by a lower court; but deportations of parents are routine and do not of themselves dictate family separation. If there were such a right, it is difficult to see why children would not also have a constitutional right to object to a parent being sent to prison or, during periods when the draft laws are in effect, to the conscription of a parent for prolonged and dangerous military service. ${ }^{136}$

Second, the two countries differ on how a parent's removal will impact their children. The United Kingdom takes the more pragmatic view that removal proceedings will directly impact children who will likely follow the removed parents. As the UK Supreme Court stated in $Z H$, "if a non-citizen parent is compulsorily removed and agrees to take her children with her, the effect is that the

133. See supra Part I.

134. See supra Part I.

135. Payne-Barahona v. Gonzales, 474 F.3d 1, 2, n.1 (1st Cir. 2007); cf. Newton v. INS, 736 F.2d 336, 342 (6th Cir. 1984) ("[A] minor child who is fortuitously born here due to his parents' decision to reside in this country, has not exercised a deliberate decision to make this country his home, and Congress did not give such a child the ability to confer immigration benefits on his parents") (citation and internal quotation marks omitted).

136. Payne-Barahona, 474 F.3d at 3. 
children have little or no choice in the matter." 137 In the United States, courts characterize children's interests as being only incidentally impacted by the removal of the parents. For example, in Cervantes v. INS, the Tenth Circuit Court of Appeals described "the enforcement of duly-enacted conditions on aliens' entrance and residence" as having only an "incidental impact on aliens' minor children."138 Five years later in 1980, the court reinforced that view: "This Court has repeatedly held that the incidental impact visited upon the children of deportable, illegal aliens does not raise constitutional problems."139 These statements also demonstrate how the evaluation of impact on children informs the treatment of citizenship, and vice versa. The court's view that any impact is only incidental makes it easier to minimize any constitutional concerns tied to the children's citizenship.

Third, differences in the legal frameworks of both countries are one of the root causes of the different approaches taken in removability determinations. The United Kingdom's status as a state party to the European Convention on Human Rights (ECHR) and the Convention on the Rights of the Child (CRC) dictates the country's approach. ${ }^{140}$ The United Kingdom has implemented those international obligations in domestic law, and ZH's legal action itself arose as a function of the country's regional obligations under article 8 of the ECHR. ${ }^{141}$ The United States, in contrast, does not have any binding regional obligations that color how it approaches the removal of non-citizen parents of citizen children. It has not ratified the CRC or otherwise implemented the Convention's provisions in its domestic law. ${ }^{142}$ Within the United States, authorities prioritize the statutory language of the INA, and the decision to grant waivers and relief is not influenced by the CRC. As such, there is no obligation that the best interest of the child be a primary consideration in determining the removability of a noncitizen parent. As the Second Circuit Court of Appeals has held, "Congress has enacted legislation defining the circumstances under which hardship to a child may appropriately be considered as a ground for granting relief from removal[.] ... This statute, and not the CRC, necessarily determines the outcome of [the applicant's] request for a hardship exception to removal." 143

Therefore, though both the United Kingdom and the United States refer to consideration of the "best interests" of the child in making certain immigrationrelated decisions, the concept is not identical in both countries. Comparing the UK Supreme Court's rationale in $Z H$ with the US Ninth Circuit Court of Ap-

137. ZH v. Sec'y of State for the Home Dep 't, [2011] UKSC 4, [1].

138. Cervantes v. INS, 510 F.2d 89, 92 (10th Cir. 1975).

139. Delgado v. INS, 637 F.2d 762, 764 (10th Cir. 1980).

140. See supra Part I.

141. See supra Part I.

142. See Roper v. Simmons, 543 U.S. 551, 576 (2005) (noting that the United States has not ratified the Convention on the Rights of the Child).

143. Oliva v. U.S. Dep't of Justice, 433 F.3d 229, 234 (2d Cir. 2005). 
peals' decision in Cabrera-Alvarez v. Gonzalez underscores the difference. ${ }^{144}$

Cabrera-Alvarez, a Mexican citizen who had lived in the United States for a decade prior to his removal proceedings, argued that his removal would result in exceptional and extremely unusual hardship for his two US citizen children, and that authorities should interpret the statutory hard-ship standard in accordance with article 3 of the CRC. ${ }^{145}$ Specifically, he contended that the hardship standard "should be interpreted consistently with the "best interests of the child" principle by giving the child's best interests extra weight in balancing the factors relevant to evaluating hardship." 146

The Court rejected that argument, opining that article 3, which pertains to actions directly affecting the child, does not have relevance to a removal proceeding as it only indirectly affects the child's interests. ${ }^{147}$ Moreover, the Court held that the CRC clearly anticipates separation of families on account of immigration-related decisions. Article 9 of the CRC, it stated, explicitly contemplates deportation of a parent and thus separation, while article 10 requires certain efforts to keep parents and children in contact once separated - a fact that implies permissible separation under the Convention. ${ }^{148}$ At most, the Court concluded, the Convention requires the best interests of the child to be a primary consideration as they already are within the context of the cancellation statute. ${ }^{149}$ The Court found no warrant under the Convention or statute for the "extra weight" argument that Cabrera-Alvarez advanced. ${ }^{150}$ According to the Court:

When an alien parent seeks cancellation of removal because of exceptional and extremely unusual hardship to a qualifying child . . . that child's 'best interests' are precisely the issue before the agency, in the sense that 'best interests' are merely the converse of 'hardship.' In other words, the agency's entire inquiry focuses on the qualifying children, making their interests a 'primary consideration' in the cancellation-of-removal analysis. ${ }^{151}$

This point, the Court held, is not undercut by the fact that the agency will weigh the competing interests rather than simply dispose of the application consistent with the finding of the "best interests" of the child. ${ }^{152}$ As the Court stated, "[t]he fact that the agency also considers the relative weight of a child's interests does not mean that the child's interests are not 'a primary consideration." "153 Within this comparative assessment, the interests of all affected parties are equally considered, and "[a]ny interpretation that required a

144. Cabrera-Alvarez v. Gonzales, 423 F.3d 1006 (9th Cir. 2005).

145. Id. at 1007 .

146. Id. at 1010

147. Id. at 1010-11.

148. See id. at 1011 .

149. Id. at 1011-12.

150. Id. at 1012 .

151. Id.

152. Id.

153. Id. 
child's best interests to be weighted more heavily than the comparative assessment would be at odds with the text of the statute." 154 In Cabrera-Alvarez, the Court did not disturb the agency's determination that his removal would not result in exceptional and extremely unusual hardship to his citizen children. Accordingly, his removal order stood.

Comparing the Ninth Circuit's decision with the UK Supreme Court's decision in $Z H$, two points of distinction are apparent. ${ }^{155}$ First, the United Kingdom uses the best interests of the child as a threshold consideration in determining the removability of a non-citizen parent. In the United States, authorities consider a citizen child's best interests only after they deem the non-citizen parent removable, at which point the question shifts to whether countervailing considerations exist that should negate removability. Although the best interests of the child are a relevant consideration in both jurisdictions, they are an affirmative consideration in the United Kingdom but a negative one in the United States (or, in the words of the Ninth Circuit, a "converse consideration"). ${ }^{156}$ In the United Kingdom, authorities take the citizen child's interests into account in their own regard to argue against deportation, whereas in the United States the consideration is whether removal would unduly impact those interests. Second, although both jurisdictions contemplate a weighing of interests, UK law elevates the best interests of the child to the initial consideration. Other evidence must then rebut a presumption of action consistent with those interests. US law, however, affords the best interests of the child equal consideration with those of other interested parties.

In short, the systems differ in their foundational approach to the question of how to weigh the child's interests. The United Kingdom approaches the issue from how removal of the non-citizen parent will impact the citizen child, while weighing other factors in that light. The United States approaches the issue from the perspective of the removable parent who has violated US immigration law, while weighing other factors and considerations under that determination.

$\mathrm{V}$.

The Removability of Non-Citizen PARENTS With Citizen CHILDREN: Is THERE A BEST APPROACH?

The United States and the United Kingdom employ different approaches for determining the removability of non-citizen parents with citizen children. Is one country's approach generally preferable to the other? The short answer is no. The approaches employed by both have pros and cons, and neither represents a "best approach" to dealing with the issue raised by this Article.

The benefits of the United Kingdom's approach include its more pragmatic

154. Id. at 1012-13.

155. See supra Part I.

156. Cabrera-Alvarez, 423 F.3d at 1012. 
view regarding the direct impact on children that removal of a non-citizen parent will have, its strong support for the interests of the citizen children, and its promotion of the value of family unity. Nonetheless, its approach gives insufficient consideration to the negative equities, including potentially flagrant violations of its immigration law. Despite claims to the contrary in $Z H$, the UK approach effectively elevates the citizenship of the child to the status of a trump card against the removal of non-citizen parents. ${ }^{157}$

The benefits of the American approach include its holistic consideration of the interests at play, especially the violation of immigration law by the noncitizen parent, and its view that relief from removal should be discretionary and only granted in sufficiently compelling circumstances. However, there are shortcomings to this approach, including its view that the removal of non-citizen parents only indirectly impacts citizen children, its onerous standard for establishing eligibility for relief from removal, and the insufficient consideration given to the child's citizenship.

A melding of the best elements in each approach would give rise to a more nuanced and complete framework within which to weigh the competing interests of the state, citizen children, and removable parents.

First, a threshold consideration that accounts for these competing interests must be set in order to orient a more nuanced and complete immigration system. This framework must operate as a discretionary mechanism where individuals who otherwise have no right to remain in a country can do so in consideration of this balance of equities. Discretion is necessary to avoid undercutting the state's prerogative to oversee an effective and orderly immigration system. No individual should have an automatic right to remain simply because he has compiled equities during the course of his illegal stay in a country. Making removal a discretionary determination also serves to protect against the possibilities of rampant abuse of the system. By making resolution of removal depend not solely on objective eligibility questions, the system makes every case unique and every determination case-dependent. As the US system currently makes clear, the presence of citizen children will not effectively forestall the removal of noncitizen parents. This general point should survive in a best approach framework via the characterization of the state's decision as discretionary.

Second, a new immigration framework must also determine how to weigh the fact of the child's citizenship. It is necessarily difficult to account for the weight of a child's citizenship in the "best interests" calculus. It should not be elevated to the point of dictating a disposition, nor should it be an ancillary interest, as it appears to be in the context of US law.

Perhaps the simplest way to reconcile these competing conceptions is to address the direct versus indirect impact dichotomy that differentiates US and UK approaches to the best interests of the child. It is unquestionably false to as-

157. See supra Parts I, III. 
sert that the removal proceedings of non-citizen parents have only an indirect impact on citizen children - especially if those children are minors. The impact is best conceived of as direct, insomuch as any determination reached in the removal proceeding will inevitably affect the citizen children. If the children depart with a parent, they are leaving their primary country of citizenship, whereas if they remain in their primary country of citizenship, removal proceedings will separate the citizen child from one or both of their parents. ${ }^{158}$ Yet how either decision impacts citizenship is not clear. It is not the case, as the UK Supreme Court asserted, that the child forfeits the benefits of citizenship if he departs. The main characterization of citizenship is the right to enter and remain in a country indefinitely, and citizen children do not sacrifice this right if they depart with their parents to a third country. To be sure, citizen children sacrifice certain benefits associated with actually residing in that country of citizenship, but that, again, does not impact the fact of citizenship or the ongoing legal relationship the children have with their country of primary citizenship.

The question of citizenship is more abstract than whether the children remain citizens and whether citizen children forfeit certain benefits of residence upon departure. The UK approach looks to the citizen children as innocent victims of their parents' violation of immigration law. ${ }^{159}$ It is true that children who obtain citizenship via the jus soli principle cannot be held accountable for their parents' violation of the law, where this violation enabled conferral of citizenship upon the children. Yet to order removal of non-citizen parents for their violation does not constitute any violation of the children's rights as citizens, as US courts have held. ${ }^{160}$

Although the children are innocent of misconduct in simply being born in the United States, that birth, especially when it is to two non-citizen parents, is properly characterized as a fortuitous accident. ${ }^{161}$ At core, then, the question is how forcefully the country of citizenship should ensure the full range of interests such children may have. The short answer is, as forcefully as is consistent within the range of other interests that the removal of the non-citizen parents raises. To order the removal of non-citizen parents is not to unduly infringe on any rights of citizen children if, on the balance of equities, the interests of removability

158. Here and elsewhere the phrase "country of primary citizenship" is used to denote, in the example of the United States, the country of citizenship stemming from application of the jus soli principle. Children born in the United States are citizens thereof, as a primary matter, but presumably they would also have an opportunity to be citizens from birth of the country of their parents' nationality and citizenship, or have an opportunity to naturalize. Dual citizenship is permissible under United States law, see Vance v. Terrazas, 444 U.S. 252, 272 (1980) (Stevens, J., concurring in part, dissenting in part), and so as long as it is permissible under the laws of the second country, children could presumably be US citizens and citizens of their parents' native countries.

159. See, for example, ZH v. Sec' 'y of State for the Home Dep't, [2011] UKSC 4, [33].

160. See Delgado v. INS, 637 F.2d 762, 764 (10th Cir. 1980); Cervantes v. INS, 510 F.2d 89, 92 (10th Cir. 1975).

161. See Newton v. INS, 736 F.2d 336, 342 (1984). 
outweigh those of the citizen children. Likewise, when the state exercises its discretion to cancel the removal of a non-citizen, either through a waiver of removability or an affirmative grant of relief, it is not by that act vindicating the interests of the citizen children, but determining that on the balance of the equities authorities should allow the non-citizen to remain in the United States despite an unlawful initial entry. The citizenship of the child is simply one additional interest in any proper weighing of the relevant equities.

Having resolved the issue of how citizenship itself should factor into the determination, this leaves only the question of where the best interests of the children should fit within the general weighing of interests in determining whether authorities should forestall the removal of a non-citizen parent. The UK Supreme Court, as well as the Ninth Circuit in Cabrera-Alvarez, referencing the Convention on the Rights of the Child, recognized that the best interests of children should be a primary consideration for authorities in determining whether to remove a non-citizen parent. In reaching its decision in $Z H$, the Supreme Court specifically rejected the assertion that the best interests should be the primary consideration. ${ }^{162}$ Yet its adoption of the Australian conception of "a primary consideration" from the Federal Court's decision in Wan effectively elevates the best interests of children to that of the primary consideration, not merely one consideration in a grouping of primary considerations. The iteration of the rule in $Z H$ is that authorities must consider the best interests of the child prior to referencing any other considerations. ${ }^{163}$ The Court did not go as far as Lord Kerr in his opinion, where he stated that "a child's best interests should customarily dictate the outcome of cases," 164 but by placing them at a level above other considerations in the hierarchy of the decision-making process, the Court in effect elevated it from the realm of merely a primary consideration. The proper approach, if the best interests of the child are simply a primary consideration, is to consider those interests on equal footing with the other considerations that will be relevant to determining removability. These interests are only one factor that could argue against removal, not the primary consideration in the authorities' determination if non-citizens should be removed, and thus there is no warrant for a framework that requires authorities to determine and address this issue before any other consideration. It is the US approach in this regard that is the preferable one, then, as it considers the interests of the child within a holistic assessment of the equities arguing both for and against removal of the non-citizen parent.

What the relevant interests are in these cases is relatively consistent across both the UK and US immigration systems. Gauging the best interests of the child will encompass comparing opportunities between the country of removal

162. $Z H$, [2011] UKSC 4 at [25] ("[D]espite the looseness with which these terms are sometimes used, 'a primary consideration' is not the same as 'the primary consideration', still less as 'the paramount consideration."').

163. Id. at [26], [33].

164. Id. at [46]. 
and destination country, including those pertaining to education, economics, and general social well being. ${ }^{165}$ Also relevant will be the health of the children, how easily the children can acclimate to life in a new culture or country, whether they have been to the destination country previously, how strong their ties to the country of removal are, how long they have lived in the country from which their parents are being removed, what family or social organization exists in the destination country, and what, if any, difficulties they may encounter in that country. ${ }^{166}$

The primary interest of the state is its right to control the terms of entry, residence, departure, and removal of non-citizens. ${ }^{167}$ Nonetheless, the exact parameters of the state's interest may also involve questions pertaining to economic interests and public safety; for instance, there may be a greater interest in removing a criminal alien than an alien who is simply removable by virtue of illegal presence. ${ }^{168}$ Authorities also consider other interests in rendering the ultimate discretionary determination relative to the applicant himself, including any criminal history, employment record in the country of removal, other avenues for legalizing his status, financial means, and immigration history. ${ }^{169}$

While there is consensus between the United States and the United Kingdom about what constitutes relevant interests, the relative weight each of these interests should receive is controversial. Proportionality, hardship, exceptional and extremely unusual hardship, and extreme hardship are standards authorities use to analyze these interests. The United Kingdom utilizes a proportionality framework that gives too little weight to the state's discretionary interest. Proportionality shifts the burden of proof from the non-citizen alien to the government: the question posed in the proportionality framework is not whether the non-citizen can marshal equities that would negate his removal, but whether the government can establish that removal is proportionate.

Though a strict interpretation of proportionality under European law would suggest that the removable alien must demonstrate that removal would not be proportionate, the case of $Z H$ and the ECtHR decisions cited therein suggest otherwise. These decisions apply proportionality by focusing on whether government action is proportionate rather than on whether the alien can demonstrate a lack of proportionality. For instance, in $Z H$, the UK Supreme Court did not focus on whether the applicant could marshal facts indicating that removal was a

165. Id. at [17]; In re Recinas, 23 I. \& N. Dec. 467, 472 (B.I.A. 2002); In re MonrealAguinaga, 23 I. \& N. Dec. 56, 63 (B.I.A. 2001).

166. ZH, [2011] UKSC 4 at [17]; In re Recinas, 23 I. \& N. Dec. at 472; In re MonrealAguinaga, 23 I. \& N. Dec. at 63; In re Mendez-Moralez, 21 I. \& N. Dec. 296, 299 (B.I.A. 1996).

167. $Z H,[2011]$ UKSC 4 at [18].

168. Id. at [18]; In re Mendez-Moralez, 21 I. \& N. Dec. at 301.

169. See In re Cervantes-Gonzalez, 22 I. \& N. Dec. 560, 565-66 (B.I.A.1999) (listing considerations relevant to discerning "extreme hardship"); 8 C.F.R. $§ 1240.58$ (b) (2010) (relating to considerations for suspension of deportation). 
disproportionate response to her unlawful presence, but rather on whether the government could demonstrate compelling interests in removal given the equities of the case. ${ }^{170}$ Likewise, the ECtHR did not require any particular showing from the applicant in the Hoogkamer case, instead focusing on whether the government's interest could overcome the interest of the mother in remaining in the Netherlands. ${ }^{171}$ This is inconsistent with what should be the discretionary nature of negating a non-citizen's removal. Given the importance of discretion, the burden should rest with the alien to establish that on consideration of all equities, the positive factors in his or her case outweigh the negative. Because authorities do not apply proportionality in this sense, it is not an appropriate standard for the instant framework.

The United States weighs the relevant interests based on varying degrees of hardship. "Simple hardship" and "exceptional and extremely unusual hardship," the extremes of any potential hardship sliding scale, are inappropriate as the governing standard in determining whether authorities should cancel removal proceedings. Showing that the citizen children may face "some hardship," a standard not currently countenanced by the INA's waiver and relief provisions, should not negate removal. Any move inevitably will result in some hardship, and such a low showing is inconsistent with a holistic weighing of the interests. If simple hardship would cancel removal, it is hard to see how the state's interests or any other negative equities would factor into the ultimate determination.

On the opposite end of the spectrum, requiring that the alien establish exceptional and extremely unusual hardship to a citizen child erects a standard so onerous that the necessity to establish extraordinary positive equities subsumes consideration of any negative equities. Citizen aliens rarely meet this standard, as the Board's jurisprudence on the issue of cancellation of removal makes clear. ${ }^{172}$ If the facts of Matter of Recinas establish the outer limit of the circumstances where authorities will be countenance removal proceedings. ${ }^{173}$ Then applying a standard of exceptional and extremely unusual hardship will not effectuate the need to fairly balance the competing interests when cases involve citizen children. Concededly, Congress desired that non-permanent residents rarely should be able to cancel their removal. ${ }^{174}$ Nevertheless, it is fair to question whether such cancellation should be as rare in reality as Congress intended in amending the statute to require such a high standard.

The US standard of "extreme hardship" reaches the proper balance by establishing that citizen children who face hardship above and beyond that which is typically associated with removal, separation of a family, or beginning a life

170. See supra Part I.

171. See supra Part I.

172. In re Recinas, 23 I. \& N. Dec., 467, 469-73 (B.I.A. 2002).

173. Id., 23 I. \& N. Dec. at 469-73.

174. See In re Monreal-Aguinaga, 23 I. \& N. Dec. 56, 59-62 (B.I.A. 2001) (citing legislative history). 
in the destination country, should forestall the removal of a non-citizen parent. It is more important for the applicant to establish that those hardships would be atypical than to establish that any hardships faced would be "extreme," as that term has been traditionally understood in the Board's jurisprudence. Though it is not clear that any explicit iteration of a standard is necessary in weighing the interests involved, the standards noted by the Board governing the various hardship determinations will be relevant. ${ }^{175}$ Those cases that would fall within the range of the Board's jurisprudence on "extreme hardship" would represent the threshold for determining that resulting hardship is atypical. ${ }^{176}$ Officials must weigh any hardship considerations against potentially negative equities, including criminal convictions, under what circumstances the citizen child or children are conceived and born, and prior immigration violations. Even if the hardship interests seem to outweigh the state's interests and any countervailing considerations, the determination of whether authorities should move forward with removal proceedings remains discretionary. This discretionary use should enable more non-citizens to successfully contest their removal than Congress intended. ${ }^{177}$ However, it should not make such success commonplace. Such action by the state is a humanitarian gesture designed to ensure family unity in a range of circumstances, not a cure-all remedy to legalize the status of individuals who have concededly broken the law and then compiled positive equities during the course of their illegal presence. Adoption of the extreme hardship standard enables a more balanced weighing of the relevant interests than the proportionality, hardship, and exceptional and extreme hardship frameworks.

In the practical application of the extreme hardship standard, some general observations are foreseeable. One set of observations involves family unity. When both parents of a citizen child are removable non-citizens, the best interests of the citizen child rarely would operate to cancel the removal of the noncitizen parents. For instance, in Matter of Monreal-Aguinaga, the applicant's non-citizen spouse already had departed the United States with one of the couple's US citizen children. ${ }^{178}$ The fact that one spouse was no longer in the United States and a citizen child had already left influenced the finding of no qualifying hardship. ${ }^{179}$ Family unity is better preserved if the child departs with the parents, neither of which has any lawful right to remain. Although the child is separated from other family living in the country of removal, this separation and the possibility of leaving the child with the other family members should be insufficient to argue against removal. ${ }^{180}$ Conversely, a lack of family in the desti-

175. See supra Part II.

176. See In re Kao \& Lin, 23 I. \& N. Dec. 45, 50-51 (B.I.A. 2001).

177. See In re Monreal-Aguinaga, 23 I. \& N. Dec. at 59-62 (citing legislative history).

178. Id.

179. Id.

180. See Cabrera-Alvarez v. Gonzales, 423 F.3d 1006, 1008 (9th Cir. 2005) ("[I]f a candidate for cancellation of removal could simply by stating that he or she would choose to have the child or 
nation country may operate as a significant factor arguing against removal. According to the dissent in Matter of Andazola-Rivas, the removal of a single mother with two citizen children from a country where the rest of her family legally resided would seem to present the type of circumstances where authorities would cancel removal proceedings. ${ }^{181}$ In the practical deliberations of relevant interests, observations regarding family unity are important.

Another set of observations involves an applicant's interactions with the country's government. History within the immigration system, including what forms of relief have been sought, granted, or denied, and whether there have been any fraudulent claims presented, is important. While the United Kingdom's ultimate disposition of ZH's article 8 application seemed to disregard the applicant's history within the immigration system, the abuse of the immigration system evident in ZH's conduct should weigh heavily against negating removal. She fraudulently sought asylum on two occasions, authorities denied lawful status under two concessions, and she had an initial article 8 application denied. ${ }^{182}$ Since the ultimate disposition of any claim will rest on a weighing of interests, it is arguable on the facts of ZH's case that despite the enormous negative equities presented, a legitimate claim arose on account of the father's precarious health and living situation. ${ }^{183}$ Nonetheless, histories of fraud and failure such as this should not culminate in the discretionary conferral of a benefit by the state. General criminal conduct also should be a relevant consideration. The more egregious or heinous the underlying criminal act, the weightier this consideration should be in the final analysis. For instance, the Board properly denied a waiver of inadmissibility in Matter of Mendez-Moralez on account of the heinousness of the underlying criminal conviction, sexual assault of a child, despite the presence of other equities. ${ }^{184}$ Though these are not bright line rules, authorities should take these general observations into account when the extreme hardship standard operates in practice.

While the adoption of the extreme hardship standard with its general observations is desirable, it is unlikely that it that the United Kingdom and the United States will adopt this standard. In the United Kingdom, the removal proceedings emerge from binding international obligations. Changing the UK system is not simply a matter of tweaking an administrative or judicial standard but requires establishing a new framework within which to determine the removability of a certain class of alien. Considering the nature of the United Kingdom's obligations, such a reorientation seems profoundly unlikely. Because the United King-

children remain in this country while he or she would go back to another country and that if such would be deemed to be the requisite degree of hardship as a practical matter the birth of the child would give the candidate for cancellation an in effect right of relief.").

181. See In re Andazola-Rivas, 23 I. \& N. Dec. 319, 320, 323-24 (2002).

182. ZH v. Sec'y of State for the Home Dep't, [2011] UKSC 4, [2].

183. Id. at 3 .

184. In re Mendez-Moralez, 21 I. \& N. Dec. 296, 302-05 (B.I.A. 1996). 
dom's systems are directly influenced in their operation by the obligations it shares as party to the CRC and ECHR, it is bound to continue applying its current framework absent a change in its conception of its obligations or a shift in the jurisprudence of the ECtHR.

In the United States, removal proceedings are statutorily based as well. However, reforms along the lines noted in this article could be possible, at least as a proposition, by adjusting administrative standards. Further, to effectuate many of the aims of this article in the context of immigration reform in the United States, simplification would be the watchword. Rather than having several different forms of relief dependent upon the status of the individual, such as whether authorities charge the alien with inadmissibility or deportability and on what specific ground of removal, one overarching type of relief should be available. The statutory eligibility questions might narrow the class of individual who could apply. For instance, the commission of an aggravated felony may render an alien ineligible for relief regardless of what other equities were in play. Yet having one form of relief for qualifying aliens and application of a uniform standard would streamline consideration of relief claims. A narrowing of the grounds of inadmissibility and deportability also would have a narrowing effect on the class of aliens subject to mandatory removal. If removability focused on criminal grounds, for instance, then many non-citizen parents would not be automatically removable by virtue of a statutory standard. Reform of this kind would move the issue away from whether authorities should grant aliens relief from removal and toward whether the government should exercise discretion in instituting proceedings against aliens residing in the United States with no lawful status. The government already has undertaken a similar approach, utilizing discretion governed by objective criteria to determine whether to institute removal proceedings against removable non-citizens. ${ }^{185}$ Among the relevant criteria for determining whether to institute removal proceedings is whether the alien has a citizen child. ${ }^{186}$

In addition to simplifying the US system, authorities could make a form of temporary relief available on a discretionary basis, such as a nonimmigrant visa available solely for non-citizen parents of minor US citizen children. Granting of the visa would be discretionary, as all such decisions are, and the visa itself would be of only temporary nature, expiring when any minor child reached the age of majority. Even in citizen families, the family begins to separate consistent with the temporal terms of the visa, with children going to college or obtaining employment often in towns and cities away from where aliens live. Expiration

185. See Memorandum from John Morton, Immigration and Customs Enforcement, "Exercising Prosecutorial Discretion Consistent with the Civil Immigration Enforcement Priorities of the Agency for the Apprehension, Detention, and Removal of Aliens" (Jun. 17, 2011), http://www.nilc.org/immlawpolicy/arrestdet/prosecutorial-discretion-J-Morton-2011-06-17.pdf.

186. Id. at 4; see Damien Cave, Crossing Over, and Over, N.Y. TIMES, Oct. 3, 2011, at A1 (discussing the Obama administration's shift to "surgical" deportations relying on the exercise of discretion in the institution of removal proceedings). 
of the visa when the citizen child turns 18 would mean that aliens could not use their visa as a bridge to lawful permanent residency via the filing of a visa petition by a 21-year-old citizen child; there would still be a period of at least three years where the parent could not lawfully reside in the United States. Yet this type of visa could ensure family unity during the formative years of a citizen child's development and its temporary nature would serve to guard against too rampant abuse of the system. Complications would arise with multiple children, but authorities could address such issues in terms of eligibility questions and the temporal duration of any status granted.

Providing affirmative relief to non-citizens who have citizen children still may encourage non-citizens to have babies in the United States. But again, authorities can always take into account the motives of non-citizens in granting the discretionary visa. If there are indications that the sole motivation for the US birth was to obtain status in this country, that could be a negative equity in the adjudication of the visa application. Overall, the streamlining of the US system and adoption of a temporary nonimmigrant visa would enable a balancing of the relevant factors more in line with the practical application of the extreme hardship standard.

While there are costs and benefits to both the UK and the US removal proceedings of non-citizen parents of citizen children, authorities can articulate the benefits of both systems in a particular policy. The United Kingdom and the United States both agree upon the relevant interests of the parents, the citizens, and the state. They disagree as to how to weigh the relevant factors. Using an extreme hardship standard would enable a fairer balancing of the interests than is currently in place in both nations. Though the feasibility of the adoption of this policy by the United Kingdom and the United States is limited, some steps towards this end are still possible.

VI.

\section{CONCLUSION}

The issues stemming from the removal of the non-citizen parents of US citizen children are likely to persist into the distant future. The illegal population in the US is not shrinking, and even if some aliens become legal via subsequent immigration reform - for example, through an amnesty - a broad swath of citizen children still will have parents without any right to remain permanently in the United States. Nonetheless, contrary to the arguments of many who assume that a citizen child effectively will forestall the removal of the non-citizen parent, the US system currently provides for few avenues for relief and those that do exist, such as cancellation of removal, often have onerous eligibility requirements. The problem of anchor babies may be more myth than reality, but there are many serious issues involved in the deportation of non-citizen parents who have citizen children. This article has proposed a general framework for weighing the competing interests of children caught up in the immigration process via 
their parents' illegality and the interests of the United States in a fairly functioning, efficient, and respected legal system. Such balancing inevitably will separate families, at times, and, at others, cancel the removal of aliens who have broken the laws of this country. No party is likely to be happy with the course of this balancing all the time, yet this is the reality of what is possible and what could prove acceptable to the relevant stakeholders.

Immigration reform may help to alleviate some of these issues by, for instance, legalizing status under certain conditions. This will shrink the population of citizen children whose non-citizen parents would be subject to removal. Reform also can more directly address this issue by focusing on the ends that US immigration law and policy should strive to obtain. If family unity is one such end, then there are compelling arguments that the relief provisions of the INA, as they currently stand, do not adequately address the factors that will be relevant to ensuring family unity - such as the best interests of US citizen children. In any event, this issue deserves serious consideration and engagement in the coming years as reforms are proposed, debated, and, hopefully implemented. 